\title{
RE-ACTUALISING THE POTENTIAL OF TEMPLES IN GREATER MALANG AS A NEW TOURIST ATTRACTION IN INDONESIA: THE NEED TO TRANSFORM REGULATIONS INTO DIGITALISED AND INTEGRATED MANAGEMENT
}

\author{
Moh FADLI \\ Department of Administrative Law, Faculty of Law, University of Brawijaya MT. Haryono, \\ No. 169, Malang, East Java, Indonesia, e-mail: mfadlifh@ub.ac.id; mfadlifhub@gmail.com

\begin{abstract}
Airin LIEMANTO*
Department of Clinic Journal, Faculty of Law, University of Brawijaya

MT. Haryono, No. 169, Malang, East Java, Indonesia, e-mail: airin.liem999@gmail.com
\end{abstract} \\ Zainal ARIFIEN \\ Civilization Studies Center, University of Brawijaya \\ Veteran Street, Malang, East Java, Indonesia, e-mail: zainal.avino1@gmail.com
}

\begin{abstract}
Citation: Fadli, M., Liemanto, A., \& Arifien, Z. (2019). RE-ACTUALISING THE POTENTIAL OF TEMPLES IN GREATER MALANG AS A NEW TOURIST ATTRACTION IN INDONESIA: THE NEED TO TRANSFORM REGULATIONS INTO DIGITALISED AND INTEGRATED MANAGEMENT. GeoJournal of Tourism and Geosites, 25(2), 474-484. https://doi.org/10.30892/gtg.25216-374
\end{abstract}

\begin{abstract}
This article is aimed to re-actualise the potential of temples located in the Greater Malang as a new sustainable tourist attraction. This paper is a legal research using statute, conceptual, and analytical approaches. The research result reveals that there are 7 aspects that play an important role in re-actualising the potential of temples located in the Greater Malang: managing the regulation systematically, revitalising organisations, developing infrastructure; Preservation by means of digital technology; improving marketing and promotion; involving the people living near the area of the temples; and improving the partnership of stakeholders. Thus, regulations are very important in developing tourism temples in Indonesia.
\end{abstract}

Key words: re-actualisation, temples, Greater Malang, new tourist attraction

$$
* * * * * *
$$

\section{INTRODUCTION}

The Greater Malang is ranging from Regency of Malang, Malang municipality, and Batu City has great potential of temples. There are 29 temples (Mahfudhoh, 2016) from the total 149 temples located in Indonesia (Dokhi et al., 2016). Badut Temple located in the Regency of Malang (National Library, n.d.) and Songgoriti Temple in Batu City (Fadli

\footnotetext{
* Corresponding author
} 
Re-Actualising the Potential of Temples in Greater Malang as a New Tourist Attraction in Indonesia: The Need to Transform Regulations into Digitalised and Integrated Management

et al., 2014) are the two oldest temples in East Java. Singasari and Majapahit Kingdom, the two greatest Hindu/Buddha kingdoms in Indonesia have also left tens of temples that serve as a symbol of the rank of their civilisation. Interestingly, Ronald Sinuwun Pralaya Jati (2017) suggests that the Greater Malang deserves its name as a Mecca for the followers of Hinduism. However, the potential has not been utilised optimally. At national level, in 2016, the foreign exchange for the state obtained from tourism sector was still at second position (Wisnubro, 2017). It is expected that by 2019 this sector could be optimised as the greatest contributor of foreign exchange to the state, as much as USD 24 billions (Ministry of Tourism of Republic of Indonesia, n.d.).

At a local level, Batu City is one of the main tourist attractions in East Java, with $65 \%$ of contribution of the total owned-source revenue (PAD) of Batu City. However, the visits by foreigners are still limited, thus improvement of promotion and the infrastructure availability is required (Christiyaningsih, 2017). In the Regency of Malang, the economy is mainly supported by agricultural and plantation sectors and trade and industrial sectors. For the tourism, the government keeps encouraging the development, in which it is expected that this sector is capable of giving optimal contribution to the owned-source revenue (Prasetyo, 2017). Despite the fact that tourist attractions available in the city are not more than the Regency of Malang and Batu have, Sutiaji (vice-Mayor of Malang) suggests that Malang may be focused more on the development of cultural art and culinary, hoping that Malang can also have the main tourism destination (Government of Malang City, 2017).

In general, temple tourism in Indonesia, especially in Greater Malang, has weaknesses in which the tourism planning has not been performed comprehensively. The planning has not involved the issuance of laws that specifically regulate how the temples are supposed to be protected and preserved, and it should also involve effective measures in terms of achieving the outcome of conservation (Liemanto, 2016). Some other shortcomings that affect the development of tourism involve limited access to road and transportation, lack of infrastructure, lack of competitiveness of tourism products offered in the market, lack of relevance to market interest, less interesting tourist objects, limited tourism promotion both at a local and international level, lack of partnership among government, private sectors, academics, NGO, and society (Cholik, 2017).

The growing development of shopping centres in the Greater Malang should be seen as a chance by the government as a way to establish partnership with private sectors in terms of developing tourist resorts at the area of the temples, which may involve the development of hotels, restaurants, and shopping centres. The existence of the weaknesses over the protection and development of temple tourism has left the temples neglected, damaged, and this condition has caused the decrease in the number Hindu visitors to the sites. This certainly causes historical and economic loss. This article is aimed to re-actualise the potential of temples located in Greater Malang by simultaneously protecting and utilising the temples as a new tourist attraction, which benefits the local government, the people living in the temple area, or the tourists. In addition to the conventional protection and utilisation, this article also elaborates how technology can be involved to add values regarding the protection and presentation of the temples that know no boundary of time and space.

\section{CONDITION AND ASSESSMENT OF TEMPLE MANAGEMENT REGARDING SUSTAINABLE TOURISM DEVELOPMENT IN GREATER MALANG}

It is inevitable that cultural heritage protection is a part of sustainable tourism development, which should meet the criteria of protection and development of cultural 
heritage. Mascardo and Woods (1998) argue that sustainable development of tourism involves 3 main aspects:

1. The quality of visitors' experience and the life of the people living near the cultural heritage site

2. Sustainable tourism

3. Sustainable development, including the balance among the needs of tourists, tourism organisers, the people living in the area, and the environment.

Liao and Wang (2011) elaborate more of the details over sustainable management of cultural heritage through the following 5 criteria:

1. Existence of Specific Regulations/ SR

The key to authenticity comprises protection and maintenance, two of which would not be realised without the existence of specific regulations to protect the cultural heritage.

2. Commercial Development/ CD

Tourism commercialisation involves the development of several facilities such as restaurants, accommodations/ hotels, shops, and so forth).

3. Tourists' understanding/ TU

The knowledge of tourism regarding the values of cultural heritage can be realised in the form education, learning, classes, workshops, or other educative activities.

4. Collaboration with Tourism Industries/ CTI

Partnership and collaboration among several parties serve as an essential key to minimising conflicts that may emerge between the tourism and the development of cultural heritage. This partnership will set a balance of several interests.

5. Safeguarding quality of life in the community/ SQLC

The development of tourism heavily relies on the participation of communities existing in the area of the cultural heritage. At the same time, this situation is also expected to improve life quality of the societies, including the increase in income obtained from ticketing (TC), infrastructural development that involves the availability of transport (TR), etc. In addition, the website (W) is also essential to be accessed by all tourists, where detailed and clear information on tourist attractions can be obtained, not to mention information on visiting hours, ticket price, location and transports available to reach the tourist objects, types of attractions, and on all other facilities provided. Based on the 6 criteria, the author aims to measure the sustainable management of the temples taking place in Greater Malang.

The tick $(\sqrt{ })$ indicates that the criteria are available, while the cross $(\mathrm{x})$ shows unavailability. The detailed measures are presented in Table 1.

From the Table 1, generally, the management of the temples has not met the criteria of sustainability, which is shown through the following indicators:

1. Specific Regulations

Protection, development, and utilisation of cultural heritage are all regulated in Regional Regulation of the Regency of Malang, Malang City, and Batu City on Cultural Heritage. However, there is no regulation of a Regent or Mayor which either technically or specifically regulates how the regional regulation regarding Cultural Heritage should be implemented on the temples, including the blue print of the plan made to sustainably develop the tourism. Specific regulation on the protection, development, and the utilisation of temples is just mentioned in Article 44 Paragraph (9) and Article 55 Paragraph (2) (a) of Presidential Decree Number 28 of 2012 on Spatial Planning of Java-Bali Island, Article 60 Paragraph (4) of Regional Regulation of the Province of East Java Number 5 of 2012 on Spatial Planning of the Regency of Malang, especially for Jago Temple, Kidal Temple, Singosari Temple, Sumberawan Temple, and Badut 
Re-Actualising the Potential of Temples in Greater Malang as a New Tourist Attraction in Indonesia: The Need to Transform Regulations into Digitalised and Integrated Management

Temple (see Figure 1 to show the temples position), while other temples have not received special attention from central and regional governments.

Table 1. Measurement of Sustainable Management of the Temples in Greater Malang

\begin{tabular}{|c|c|c|c|c|c|c|c|c|}
\hline \multirow{2}{*}{ No } & \multirow{2}{*}{ Temple } & \multirow{2}{*}{ SR } & \multirow{2}{*}{ CD } & \multirow{2}{*}{ TU } & \multirow{2}{*}{ CTI } & \multicolumn{2}{|c|}{ SQLC } & \multirow{2}{*}{$\mathbf{W}$} \\
\hline & & & & & & TC & TR & \\
\hline 1 & Jago Temple & $\sqrt{ }$ & $\mathrm{X}$ & $\sqrt{ }$ & $\mathrm{X}$ & $\mathrm{X}$ & $\sqrt{ }$ & $\sqrt{ }$ \\
\hline 2 & Kidal Temple & $\sqrt{ }$ & $\mathrm{X}$ & $\sqrt{ }$ & $\mathrm{X}$ & $\mathrm{X}$ & $\mathrm{X}$ & $\sqrt{ }$ \\
\hline 3 & Singosari Temple & $\sqrt{ }$ & $\mathrm{X}$ & $\sqrt{ }$ & $\sqrt{ }$ & $\sqrt{ }$ & $\sqrt{ }$ & $\sqrt{ }$ \\
\hline 4 & Sumberawan Temple & $\sqrt{ }$ & $\mathrm{X}$ & $\sqrt{ }$ & $\sqrt{ }$ & $\sqrt{ }$ & $\mathrm{X}$ & $\sqrt{ }$ \\
\hline 5 & Selokelir Temple & $\mathrm{X}$ & $\mathrm{X}$ & $\mathrm{X}$ & $\mathrm{X}$ & $\mathrm{X}$ & $\mathrm{X}$ & $\sqrt{ }$ \\
\hline 6 & Complex of Jawar Ombo Temple & $\mathrm{X}$ & $\mathrm{X}$ & $\mathrm{X}$ & $\mathrm{X}$ & $\sqrt{ }$ & $\mathrm{X}$ & $\sqrt{ }$ \\
\hline 7 & Bocok Temple & $\mathrm{X}$ & $\mathrm{X}$ & $\mathrm{X}$ & $\mathrm{X}$ & $\mathrm{X}$ & $\mathrm{X}$ & $\mathrm{X}$ \\
\hline 8. & Petirtaan Watugede & $\mathrm{X}$ & $\mathrm{X}$ & $\sqrt{ }$ & $\mathrm{X}$ & $\sqrt{ }$ & $\mathrm{X}$ & $\mathrm{X}$ \\
\hline 9 & Ngabab Temple & $\mathrm{X}$ & $\mathrm{X}$ & $\mathrm{X}$ & $\mathrm{X}$ & $\mathrm{X}$ & $\mathrm{X}$ & $\mathrm{X}$ \\
\hline 10 & Gunung Telih Temple & $\mathrm{X}$ & $\mathrm{X}$ & $\mathrm{X}$ & $\mathrm{X}$ & $\mathrm{X}$ & $\mathrm{X}$ & $\mathrm{X}$ \\
\hline 11 & Badut Temple & $\sqrt{ }$ & $\sqrt{ }$ & $\sqrt{ }$ & $\sqrt{ }$ & $\sqrt{ }$ & $\sqrt{ }$ & $\sqrt{ }$ \\
\hline 12 & Songgoriti Temple & $\mathrm{X}$ & $\sqrt{ }$ & $\sqrt{ }$ & $\sqrt{ }$ & $\mathrm{X}$ & $\sqrt{ }$ & $\sqrt{ }$ \\
\hline 13 & Punden Mojorejo & $\mathrm{X}$ & $\mathrm{X}$ & $\mathrm{X}$ & $\mathrm{X}$ & $\mathrm{X}$ & $\mathrm{X}$ & $\mathrm{X}$ \\
\hline \multicolumn{9}{|c|}{ Kompleks Percandian Gunung Arjuna } \\
\hline \multicolumn{9}{|c|}{ a. Sepilo Group } \\
\hline 14 & Bhatara Guru Temple & $\mathrm{X}$ & $\mathrm{X}$ & $\mathrm{X}$ & $\mathrm{X}$ & $\mathrm{X}$ & $\mathrm{X}$ & $\mathrm{X}$ \\
\hline 15 & Kembang Temple & $\mathrm{X}$ & $\mathrm{X}$ & $\mathrm{X}$ & $\mathrm{X}$ & $\mathrm{X}$ & $\mathrm{X}$ & $\mathrm{X}$ \\
\hline 16 & Lepek Temple & $\mathrm{X}$ & $\mathrm{X}$ & $\mathrm{X}$ & $\mathrm{X}$ & $\mathrm{X}$ & $\mathrm{X}$ & $\mathrm{X}$ \\
\hline 17 & Madrin Temple & $\mathrm{X}$ & $\mathrm{X}$ & $\mathrm{X}$ & $\mathrm{X}$ & $\mathrm{X}$ & $\mathrm{X}$ & $\mathrm{X}$ \\
\hline 18 & Wesi Temple & $\mathrm{X}$ & $\mathrm{X}$ & $\mathrm{X}$ & $\mathrm{X}$ & $\mathrm{X}$ & $\mathrm{X}$ & $\mathrm{X}$ \\
\hline 19 & Hyang Semar Temple & $\mathrm{X}$ & $\mathrm{X}$ & $\mathrm{X}$ & $\mathrm{X}$ & $\mathrm{X}$ & $\mathrm{X}$ & $\mathrm{X}$ \\
\hline 20 & Makutarama Temple & $\mathrm{X}$ & $\mathrm{X}$ & $\mathrm{X}$ & $\mathrm{X}$ & $\mathrm{X}$ & $\mathrm{X}$ & $\mathrm{X}$ \\
\hline 21 & Patung Lesung Temple & $\mathrm{X}$ & $\mathrm{X}$ & $\mathrm{X}$ & $\mathrm{X}$ & $\mathrm{X}$ & $\mathrm{X}$ & $\mathrm{X}$ \\
\hline 22 & Rancang Kencana Temple & $\mathrm{X}$ & $\mathrm{X}$ & $\mathrm{X}$ & $\mathrm{X}$ & $\mathrm{X}$ & $\mathrm{X}$ & $\mathrm{X}$ \\
\hline 23 & Rhatawu Temple & $\mathrm{X}$ & $\mathrm{X}$ & $\mathrm{X}$ & $\mathrm{X}$ & $\mathrm{X}$ & $\mathrm{X}$ & $\mathrm{X}$ \\
\hline 24 & Sepilo Temple & $\mathrm{X}$ & $\mathrm{X}$ & $\mathrm{X}$ & $\mathrm{X}$ & $\mathrm{X}$ & $\mathrm{X}$ & $\mathrm{X}$ \\
\hline 25 & Watu Ireng Temple & $\mathrm{X}$ & $\mathrm{X}$ & $\mathrm{X}$ & $\mathrm{X}$ & $\mathrm{X}$ & $\mathrm{X}$ & $\mathrm{X}$ \\
\hline \multicolumn{9}{|c|}{ b. Indrokilo Group } \\
\hline 26 & Laras Temple & $\mathrm{X}$ & $\mathrm{X}$ & $\mathrm{X}$ & $\mathrm{X}$ & $\mathrm{X}$ & $\mathrm{X}$ & $\mathrm{X}$ \\
\hline 27 & Gua Gambir & $\mathrm{X}$ & $\mathrm{X}$ & $\mathrm{X}$ & $\mathrm{X}$ & $\mathrm{X}$ & $\mathrm{X}$ & $\mathrm{X}$ \\
\hline 28 & Indrikilo & $\mathrm{X}$ & $\mathrm{X}$ & $\mathrm{X}$ & $\mathrm{X}$ & $\mathrm{X}$ & $\mathrm{X}$ & $\mathrm{X}$ \\
\hline 29 & Satria Manggung & $\mathrm{X}$ & $\mathrm{X}$ & $\mathrm{X}$ & $\mathrm{X}$ & $\mathrm{X}$ & $\mathrm{X}$ & $\mathrm{X}$ \\
\hline
\end{tabular}

Sources: author analyses from many sources (http://candi.perpusnas.go.id/temples/deskripsi-jawa_timurcandi_badut.; http://candi.perpusnas.go.id/temples/deskripsi-jawa_timur-candi_singasari.;

https://candi.perpusnas.go.id/temples/deskripsi-jawa_timur-candi_jago.;

https://candi.perpusnas.go.id/temples/deskripsi-jawa_timur-candi_kidal.;

https://www.eastjava.com/tourism/malang/sumberawan-temple.html.; https://ngalam.co/2016/o6/o3/candijawar-ombo-ampelgading/; https://situsbudaya.id/candi-songgoriti-kota-batu-jawa-timur/)

\section{Commercial Development}

Commercial development of tourism has been well executed in two locations: Songgoriti Temple and Badut Temple, while other 27 locations are rarely provided with hotels, restaurants, and souvenir shops. Unfortunately, this condition has left the economic potential neglected and tourist attractions are decreasing in popularity. 
2. Tourists' understanding

The tour guides with the knowledge of the history of temples are only available in 7 tourism locations and in Indonesian language only, while other forms of activities such as seminar, short courses, and scientific writing contest have never been conducted due to the shortage of potential human resource and fund.

3. Collaboration with Tourism Industry

Partnership in tourism industry is mainly focused on temples that receive attention from the government to be developed further into a main tourist attraction such as Singosari Temple, Sumberawan Temple, and Badut Temple, and Songgoriti Temple. On the other hand, other tourist attractions, with all their limit in infrastructures, have not received any attention.

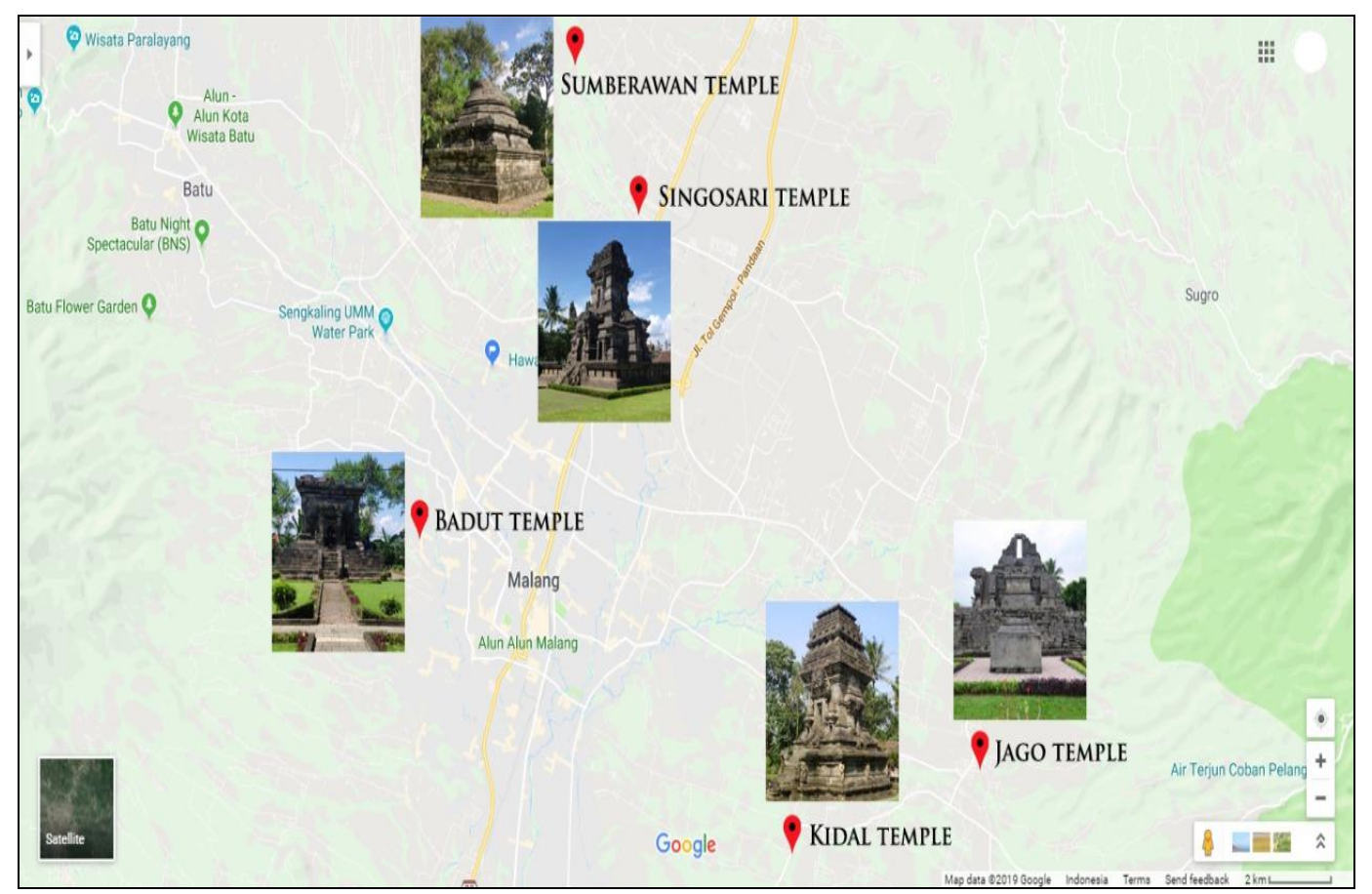

Figure 1. Temples' positions

4. Safeguarding the quality of life in the community

The improvement of the quality of life of the locals living in the area of the temples is minimum. There are only 5 temple objects levying entrance fee. The amount imposed is relatively small to about Rp. 10.000. This will not certainly have huge impact on the improvement of the quality of life of the people living in temple areas. Furthermore, only four temples are supported by public transports that bring visitors right to the destination. Therefore, this issue needs more attention from the government.

5. Website

Website plays an important role in giving information and supporting promotion of tourist attractions. However, there are only 8 tourist objects that utilise website to market and promote their tourist attractions, indicating a bad tourism management. 
Re-Actualising the Potential of Temples in Greater Malang as a New Tourist Attraction in Indonesia: The Need to Transform Regulations into Digitalised and Integrated Management

\section{RE-ACTUALISING THE POTENTIAL OF TEMPLES IN GREATER MALANG AS A NEW TOURIST ATTRACTION}

Based on Strategic plan of the Ministry of Tourism 2015-2019 and Strategic Target of the Ministry of Tourism in Medium-term Development Planning (RPJM) 2015 - 2019, the government is planning to turn the tourism into a core economy in Indonesia, in which the tourism industry in Indonesia is projected to be the biggest source of foreign exchange in the state, the best tourism in ASEAN, increase the rank of Wonderful Indonesia at international level, and Indonesia is also expected to be a Tourism Hub by 2019 (Bureau of Planning and Finance of Ministry Secretariat, 2016).

Recalling that the need for cultural heritage tourism is gaining its importance and the fact that there is an increase in interest of both foreign and local tourists, the tourism requires holistic and integrated handling that involves digitalisation. The concept of cultural heritage tourism integrates aspects required in a research, the development of sites, design, planning, construction, technology, preservation, interpretation, and customer services by putting theories into practices of tourism (Jamieson, 1998). To re-actualise the potential of the temples in Greater Malang as a new tourist attraction, the author suggests that there should be improvement of regulation that provides the following main notions:

1. Improvement of regulations covering regional and central areas

At international level, Indonesia has ratified the 1972 World Heritage Convention by issuing a Presidential Decree Number 26 of 1989. To take the further action regarding this ratification, the government has also put the Law Number 11 of 2011 on Cultural Heritage into effect, which is used as a reference in terms of the application of regional regulations in Indonesia. In addition to applying laws that are aimed to protect, develop, and utilise cultural heritage, the government is expected to consider short-term, mediumterm, and long-term plans in order to protect, take care of, and present the objects of cultural heritage. The scope of the cultural heritage should involve two aspects as follows:

i. Material involves (a) zonation; (b) infrastructure development such as road maintenance, public transport improvement, provision of tour guides, development of restaurants and accommodations, and so forth; and (c) strengthening the management of cultural heritage.

ii. Non-material takes perception and cohesiveness.

As to protect the cultural heritage in the long run, regular monitoring and report are required. When monitoring is done regularly, quick response can be gained in case of trouble occurring in cultural heritage management (Liemanto, 2016).

However, several regional regulations of cultural heritage merely serve as the norm that is not easy to implement. Thus, improvement of the regulations is required to make them more effective, where the good characteristics of the formation of the norm regarding cultural heritage should be met as follows (UNESCO, ICCROM, ICOMOS \& IUCN, 2013):

a. Clear regulation of inventory, protection, zonation of cultural heritage area, and intervention policy.

b. Clear command and coordination line required in a teamwork and wide access to consultation and participation.

c. Existence of provision that integrates all the local potentials into a sustainable tourism development system.

d. Capacity to utilise other related-regulations either at central level or regional level for the sake of the protection and utilisation of cultural heritage.

e. The need of management in terms of power distribution. This criterion is aimed to give closer access to the objects of cultural heritage and problem solver. 
f. The need of provision that allows different systems and the monitoring of the impacts. It is expected that experiments still go on to realise better management of cultural heritage.

2. Revitalising institutional bodies from the central to regional areas

The institution responsible for the protection, development, and utilisation of cultural heritage at national level is under the Directorate General of Culture, the Ministry of Education and Culture. Based on the Law Number 11 of 2011 on Cultural Heritage, the obligation and authority of the central government, provincial government, and the government of the regency/municipality are not clearly elaborated. This hinders the command and coordination line in teamwork. Therefore, amendment of the Law of Cultural Heritage is required, where the local government in the regency and municipality should hold a key role in protection, development, and utilisation of cultural heritage for a quicker decision making and more organised technical stuff.

Furthermore, Indonesia has limited human resource in archaeology. This is the responsibility of the government to adequately develop the capacity of the human resource for a more sustainable cultural heritage management and more solid institutions and community of a wider scope. The development of the capacity will be focused more on several aspects (WHC-11/35.COM/9B):

i. Reinforcement of human resource from the aspects of knowledge, skill, and attitude to be directly responsible for protection and cultural heritage management.

ii. Improvement of structure and strategic policy making in an institution

iii. Implementation of more dynamic relationship between cultural heritage objects and their context by means of more inclusive approaches.

3. Development of infrastructure

The development of infrastructure is the key requirement for a sustainable tourism development. Temples located in Greater Malang have not met the standard requirement regarding the infrastructure standard set by UNESCO. For example, Gunung Telih Temple is located in a remote area, and it can only be accessed on foot or by motorbike. This location is $4 \mathrm{~km}$ from the nearest Donogragal hamlet, Donowarih village, the district of Karangploso. Some other 16 temples located within the area of enshrinement in Arjuna Mountain are also difficult to access and they are lack of adequate facilities for tourists. Worse still, Bocok Temple located in Bocok hamlet, Pondokagung village, the district of Kasembon, the Regency of Malang has been stolen due to the lack of proper security. The development of infrastructure should be prioritised to realise sustainable tourism development. It is essential that the government provide facilities and effective services to fulfil the need of the tourists, along with the provision of easy access to the temples. The facilities developed for the tourists should involve (a) road access; (b) public transports to the location; (c) signposts, lane, information, and guidelines; (d) availability of museum or exhibition for the temples; (e) the availability of bilingual tour guides; (f) Utilisation of technology and digital services; (g) other accommodations and facilities such as inns/hotels, restaurants, shopping centres, parking lot, toilets, search and rescue team, and so forth .

4. Preservation by means of digital technology

The utilisation of digital technology has made a huge and substantial change regarding the protection, development, and presentation of cultural heritage. The existence of big data has directly impacted data restoration and data/information diversion. Big data "reflects the growing technological ability to capture, aggregate, and process an ever-greater volume, velocity, and variety of data sets" (Supriyadi, 2017). Information on things related to the temples can be accessed on website for all people 
Re-Actualising the Potential of Temples in Greater Malang as a New Tourist Attraction in Indonesia: The Need to Transform Regulations into Digitalised and Integrated Management

around the globe. Moreover, technology can be utilised to present the temples in a more attractive form, especially for young generation.

There are several forms of technology that could be utilised to help tourists enjoy more of the cultural heritage in $3 \mathrm{D}$ images, immersive technologies, augmented reality, virtual reality, video reconstructions and simulations. This is a great chance as those technologies could be made at a relatively low cost since it is supported by open source software. Therefore, temples can be presented in a more attractive and interesting way.

The utilisation of technology is also popular when it is presented in the form of games. Games give users education in a fun way, not only restricted to children, but adults could also use this facility. As commonly known, games are varied in their types as follows: (1) a game that is played individually, played in a small group of players, and played by several teams; (2) games are educative and neutral; (3) games that require special devices, high-tech games, games based on simple objects and symbols; (4) games based on certain orders or behaviours; (5) games (not) relying on physical activities; (6) games (not) requiring physical involvement of the players; (7) games requiring special knowledge and skills; (8) simulation or abstract games; (9) games requiring chances and skills; (1) games making the winner or those not; and many more (Ronchi, 2009).

As a result, games can serve as a new alternative approach to attract more people to appreciate cultural heritage of the past presented in a modern way.

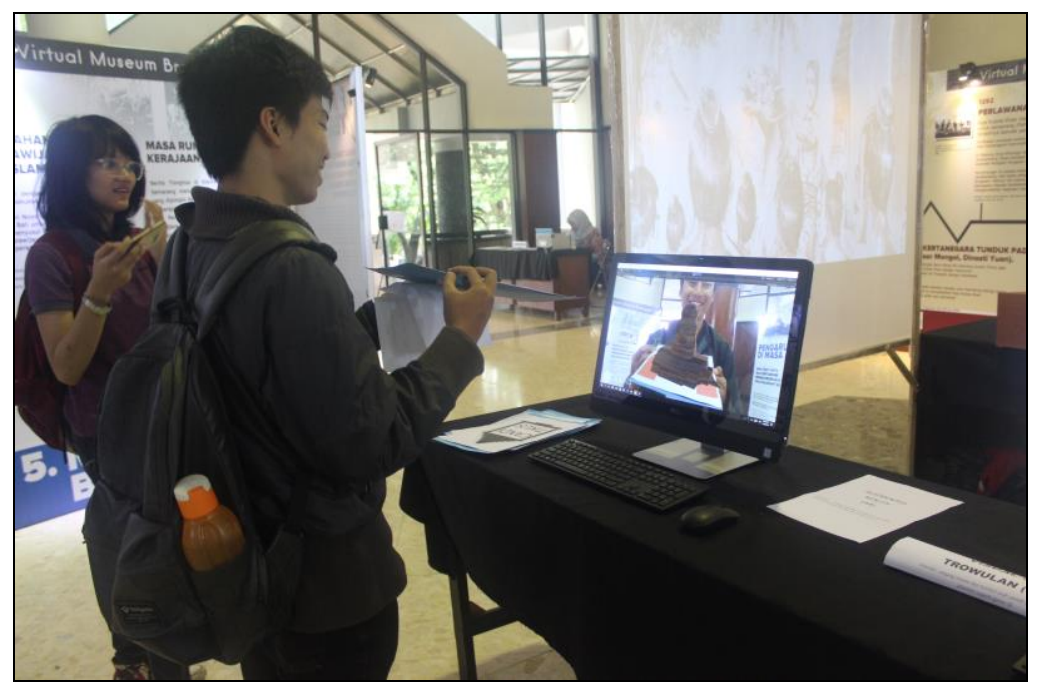

Figure 2. Example of the Utilisation of Augmented Reality on Presenting Temples

\section{Increasing marketing and promotion}

There is still lack of promotion of the temples located in Greater Malang, which is due to the absence of official website made by the government or any parties in charge to promote the temples as tourism objects. The government is responsible to encourage the promotion of cultural heritage tourism that can help increase the quality and quantity of tourism. The regulations regarding marketing and promotion strategies for tourism by building image needs to be more developed. Furthermore, Tourism Department, along with private sectors, should provide public information centre and consultation service to give information on tourist attractions, route to the tourist objects, public transportation, weather, accommodation, security, and nearest health clinic in case of emergency. 
Since most of the temples in Malang sit in remote areas where the access to the spots is very limited, utilisation of software 'Visit Malang' could be encouraged to give information regarding the tourism in Malang, alternative road that can be taken, hotels, restaurants, and nearest service station that can be reached by tourists.

Besides, reinforcing marketing and promotion strategies needs to be focused more on foreign tourism by providing information on the website in two languages: Indonesian and English. This also needs to be supported with the availability of shops selling souvenirs in varied range and high quality, which should meet the market taste.

6. Participation of community living at the temple areas

The development of tourism industries heavily relies on the participation of communities. The participation can be performed through (a) information; (b) consultation; (c) collaboration; and (d) empowerment (Kuncoro \& Zulkaidi, 2015).

In addition, the community living in the area of the temples must be actively involved to protect, maintain, and utilise the tourism objects so that they are expected to have a sense of belonging. The development of the culture of the society taking place around the temples through several continuous efforts by public and private institutions will surely give positive influences in terms of reviving the identity of the communities living in the areas of the temples. It will also help them improve their economic status and positively contribute to the sustainable development of tourism.

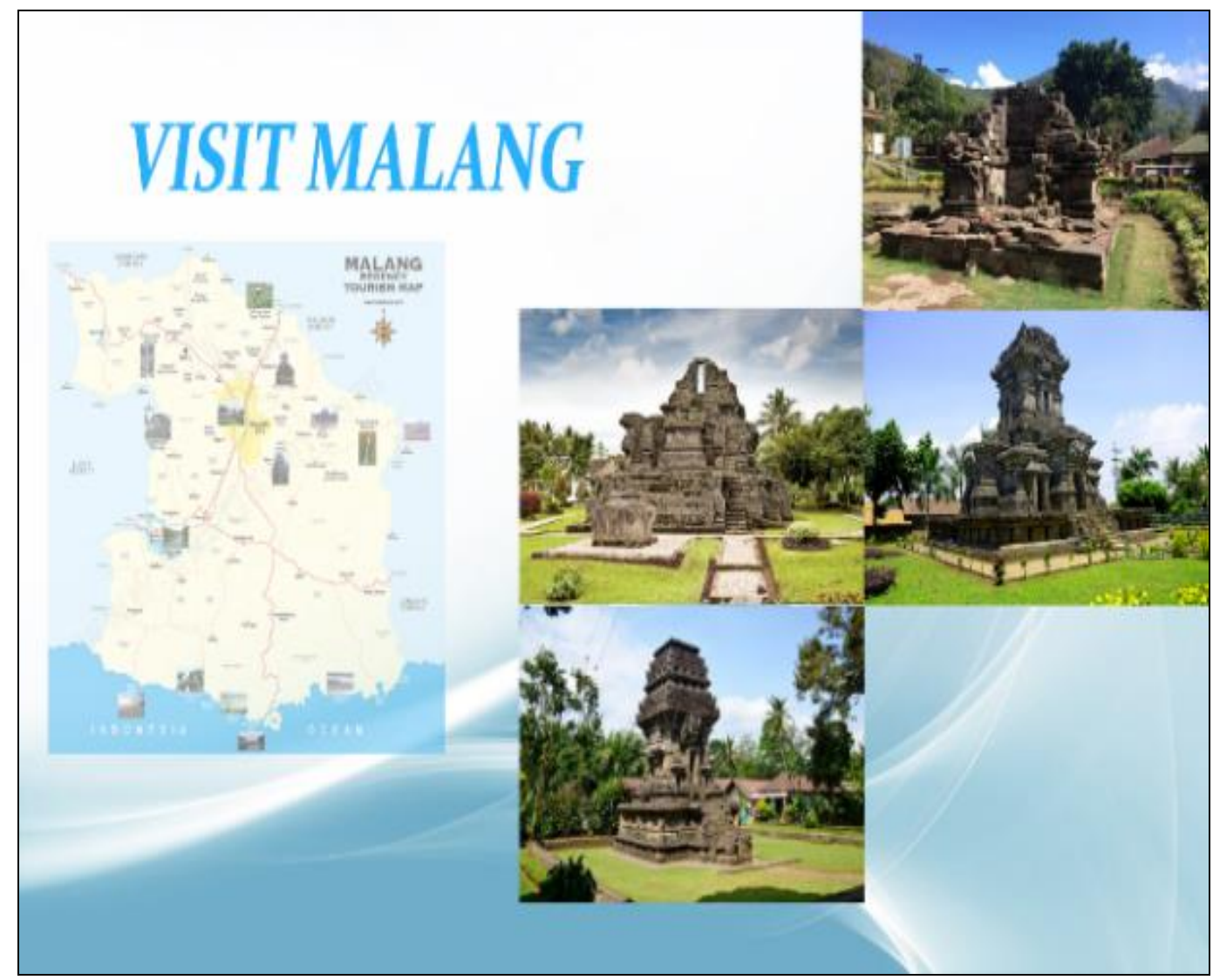

Figure 3. Example of Visit Malang Software 
Re-Actualising the Potential of Temples in Greater Malang as a New Tourist Attraction in Indonesia: The Need to Transform Regulations into Digitalised and Integrated Management

\section{Increasing partnership among stakeholders}

The partnership established among government, academics, private sectors, NGO, and communities is highly required. Partnership model for cultural heritage tourism should be explored, involving planning, management, marketing, and funding. The government can work with private sectors to provide initial funds to financially support the tourism.

\section{CONCLUSION}

The area of Greater Malang has a big potential for temple tourism, but the management performed by the government along with private sectors is not optimal yet. The management of 29 temples located in Greater Malang has not met the parameters required in the sustainable development of tourism. Re-actualising the potential of the temples located in Greater Malang as a new tourist attraction is required holistically and in an integrated way. This re-actualisation surely needs improvement of the regulations that consist of several main ideas: (a) More systematic management of regulation ranging from central to local governance; (b) revitalisation of institutional bodies from central to regional governance; (c) development of infrastructure; (d) preservation by means of digital technology; (e) improvement of marketing and promotion; (f) Participation of the communities living near the location of the temples; and (g) Increasing partnership among stakeholders. Recommendation: It is essential that re-management of the existing regulations must be performed to bring temple tourism to a digital-based tourism for a more optimised historical potential with more economic values.

\section{REFERENCES}

Cholik, A. (2017). The Development of Tourism Industry in Indonesia: Current Problems and Challenges. European Journal of Research and Reflection in Management Sciences, 5 (1), pp. 54-55.

Dokhi, M., Siagian T. H., Sukim, Wulansari, I. Y, Hadi, D. W. \& Sambodo, N. (2016). Analisis Kearifan Lokal Ditinjau dari Keragaman Budaya Tahun 2016 (Analyses of Local Wisdom from the Perspective of Cultural Diversity Year 2016). Data and Statistics of Centre of Education and Culture, Ministry of Education and Culture, pp. 58-59.

Fadli, M., Hamidi, J. \& Harianto, D. (2014). Sejarah Candi dan Sumber Mata Air Songgoriti: Pendekatan Supranatural (History of Temple and Water Sources of Songgoriti: Supernatural Approach), UB Press, Malang, pp. 4.

Jamieson, W. (1998). Cultural Heritage Tourism Planning and Development: Defining the Field and Its Challenges. APT Bulletin, Vol. 29, No. 3/4, Thirtieth-Anniversary Issue 1998, pp. 65.

Jati, R. S. P. (2017). Interview with authors in Nuswantara Civilisation Centre, Jalan Simpang Panji Suroso Blok A4., No. 5, Malang, Jawa Timur, Indonesia on November 12.

Kuncoro, T. S. \& Zulkaidi, D. (2015). Community Participation in Preservation of Cultural Heritage Buildings in Surakarta City (Partisipasi Masyarakat dalam Pelestarian Bangunan Cagar Budaya di Kota Surakarta). Jurnal Perencanaan Wilayah dan Kota B SAPPK V4N1, pp. 203.

Liao, D \& Wang, P. (2011). Sustainable Tourism Development - How Sustainable Are China's Cultural Heritage Sites. In Proceedings of the Northeastern Recreation Research Symposium, pp. 1-2.

Liemanto, A. (2016). Protection of Cultural Heritage in China and Indonesia: An Examination under the 1972 World Heritage Convention, Unpublished Master Thesis, Faculty of Law, China University of Political Science and Law, China.

Mahfudhoh, L. (2016). Antologi sejarah Candi Boyolangu (Historic Anthology of Boyolangu Temple), Guepedia, Bogor, pp. 25-30.

Moscardo, G., \& Woods, B. (1998). Managing Tourism in the Wet Tropics World Heritage Area: Interpretation and the experience of vsitors on Skyrail. In E. Laws, B. Faulkner \& G. Moscardo (Eds.), Embracing and Managing Change in Tourism: International Case Studies, Routledge, London.

Prasetyo, S. E. (2017). Dewan Pertanyakan Proyeksi Target PAD Kabupaten Malang (The Council Questioned the Projected Target of Local Revenue of Malang Regency). Retrieved from: https://www.jawapos.com/jpg-today/25/10/2017/dewan-pertanyakan-proyeksi-target-pad-kabupatenmalang. [Accessed 10 June 2018]. 
Ronchi, A. M. (2009). Culture: Cultural Content in the Digital Age, Springer, Verlag Berlin Heidelberg, pp. 158.

*** Bureau of Planning and Finance of Ministry Secretariat. Report of Performance of Ministry of Tourism Year 2016. Retrieved from: http://www.kemenpar.go.id/userfiles/LAPORAN\%2oKINERJA\%2OKEMENPAR \%202016_FINAL.pdf. [Accessed 10 June 2018].

*** Christiyaningsih. (2017). Pemkot Batu Targetkan Kunjungan 4,2 Juta Wisatawan Tahun Ini (Local Government of Batu City Targeting 4.2 Million Tourist Visits This Year). Retrieved from: https://www.republika.co.id/berita/nasional/daerah/17/o2/19/olmotp359-pemkot-batu-targetkankunjungan-42-juta-wisatawan-tahun-ini. [Accessed 10 June 2018].

*** Government of Malang City. (2017). Pariwisata Berperan Dongkrak Sektor Ekonomi (Tourism Plays a Role in Enhancing Economic Sector). Retrieved from: https://malangkota.go.id/2017/10/02/ pariwisataberperan-dongkrak-sektor-ekonomi/. [Accessed 10 June 2018].

*** Indonesian Strategic plan of the Ministry of Tourism 2015-2019.

*** Indonesian Strategic Target of the Ministry of Tourism in Medium-term Development Planning (RPJM) 2015-2019.

*** Law of the Republic of Indonesia Number 11 of 2011 on Cultural Heritage

*** Malang Tourism. (n.d.). Sumberawan Temple: The Second Buddhist Temple Style in East Java - Built About 14th Century. Retrieved from: https://www.eastjava.com/tourism/malang/sumberawan-temple.html. [Accessed 11 June 2018].

*** MalangMbois, (2016). Candi Jawar Ampelgading, Peninggalan Majapahit (Jawar Ampelgading Temple, Majapahit heritage). Retrieved from: https://ngalam.co/2016/o6/o3/candi-jawar-ombo-ampelgading/. [Accessed 6 September 2018].

*** Ministry of Tourism of the Republic of Indonesia. (2017). Kerja Bersama: Capaian Sektor Pariwisata 3 Tahun Jokowi-JK (Collaboration Works: Achievement of Tourism Sector in 3 years of Jokowi-JK). Retrieved from: http://presidenri.go.id/wp-content/uploads/2017/10/KEMENPAR-Laporan-3-ThJkw-JK.pdf. [Accessed 10 June 2018].

*** National Library. (n.d.). "Candi Jago (Jago Temple). Retrieved from: https://candi.perpusnas.go.id/ temples/deskripsi-jawa_timur-candi_jago. [Accessed 10 June 2018].

*** National Library. (n.d.). Candi Kidal (Kidal Temple). Retrieved from: https://candi.perpusnas.go.id/ temples/deskripsi-jawa_timur-candi_kidal. [Accessed 10 June 2018].

*** National Library. (n.d.). Candi Singasari (Singasari Temple). Retrieved from: http://candi.perpusnas.go.id/ temples/deskripsi-jawa_timur-candi_singasari. [Accessed 10 June 2018].

*** National Library. (n.d.). Candi Badut (Badut Temple). Retrieved from: http://candi.perpusnas.go.id/ temples/deskripsi-jawa_timur-candi_badut. [Accessed 10 June 2018].

*** Presidential Decree of the Republic of Indonesia Number 26 of 1989 on Ratification of Convention concerning the Protection of the World Cultural and Natural Heritage.

*** Presidential Decree of the Republic of Indonesia Number 28 of 2012 on Spatial Planning of Java-Bali Island

*** Regional Regulation of the Province of East Java Number 5 of 2012 on Spatial Planning of the Regency of Malang.

*** Situs Budaya. Candi Songgoriti, Kota Batu Jawa Timur (Songgoriti Temple, Batu City East Java). Retrieved from: https://situsbudaya.id/candi-songgoriti-kota-batu-jawa-timur/. [Accessed 10 September 2018].

Supriyadi, D. (2017). Personal and Non-Personal Data in the Context of Big Data, Unpublished Master Thesis, Tilburg Institute for Law, Technology and Society, pp. 12.

*** The 1972 UNESCO Convention concerning the Protection of the World Cultural and Natural Heritage.

*** UNESCO, ICCROM, ICOMOS \& IUCN. (2013). Managing Cultural World Heritage, UNESCO, France, pp. 66.

*** Wisnubro. (2017). Tiga Tahun Jokowi-JK, Pariwisata Sumbang Devisa Terbesar Kedua (Three Years of Jokowi-JK, Tourism Contributes Second Largest Foreign Exchange). Retrieved from: https://jpp.go.id/ekonomi/pariwisata/311908-pariwisata-penyumbang-terbesar-nomor-dua-devisaindonesia. [Accessed 10 June 2018].

*** World Heritage Committee. World Heritage Strategy for Capacity Building. WHC-11/35.COM/9B, pp. 3-4.

Submitted:

02.02.2019
Revised:

14.05.2019
Accepted and published online 05.06.2019 